\title{
Evaluation of the Performance of Two Strains of Nile Tilapia (Oreochromis Niloticus) In Mixed Raising Systems
}

\author{
Patrícia Ribeiro Neves ${ }^{1 *}$, Ricardo Pereira Ribeiro ${ }^{1}$, Lauro $\operatorname{Vargas}^{1}$, Maria Raquel Marçal \\ Natali $^{1}$, Káttia Regina Maehana ${ }^{1}$ and Nilton Garcia Marengoni ${ }^{2}$ \\ ${ }^{I}$ Universidade Estadual de Maringá; Avenida Colombo 5790; 87020-900; Maringá - PR - Brazil. ${ }^{2}$ Universidade do \\ Oeste do Paraná - Unioeste; Marechal Cândido Rondon - PR - Brazil
}

\begin{abstract}
The aim of this study was to evaluate the productive performance of two strains of Nile tilapia (Oreochromis niloticus) in mixed raising systems. A total of 3600 fish-larvae species was used, 1800 belonging to Bouaké lineage, and 1800 to Chitralada. The experiment was carried out in three phases; Phase I in an incubator in 18 boxes, in which two treatments (Bouaké and Chitralada) were tested by using nine repetitions; Phases II and III were performed in 18 cement tanks with the same treatments. In phase I, regarding the final weight and gain of weight, Chitralada strain showed the highest final weight values. In phase II, Chitralada showed the highest final weight value when compared with Bouaké, and, considering the gain of weight, Bouaké obtained the best result. In phase III, Chitralada showed better final weight results (104 days of raising), final weight, final length and gain of length/cm (152 days of raising); but, after 279 days of the cultivation, Bouaké showed a higher weight and length gain. These findings showed that Chitralada strain presented the best performance.
\end{abstract}

Key-words: Performance, Strains, Oreochromis niloticus, Reproduction, Nile tilapia

\section{INTRODUCTION}

According to FAO (2003), in 2002, the fishing and worldwide aquaculture conditions has shown an increase of $9.2 \%$ in the production from 1970, in comparison to the only $1.4 \%$ of the extractive fishing and $2.8 \%$ terrestrial animals production. China remains as the biggest producer, with $71 \%$ of the volume and about 50\% in terms of the value. In 2001, 142.1 million tons of fishery were produced (either from the fishing or from the aquaculture). This showed that the activity contributed with more than 48.4 million tons, equivalent to U\$ 61.4 billions (Borghetti et al., 2003). Due to this explosion in the aquaculture, the fishes worldwide production also significantly increased in the last 12 years. The production increased from 8.6 million tons to 24.4 millions tons in 2001 (Borghetti et al., 2003).

Tilapias are one of the most cultivated species all over the world, being the third worldwide production with $5.7 \%$, followed by both the cyprinid fish species that represent $87.2 \%$ of the total amount of the fishes cultivated in the world, and the salmonoid fish species that correspond to about $7.2 \%$ of the fish production (Borghetti et al., 2003). The worldwide production of tilapia in the latest years was significantly influenced by the fast expansion of the $O$. niloticus specie, raised in China, Philippines, Thailand, Indonesia and Egypt. From 1984 to 1995 , raising showed a significant increase from $38 \%$, that is, 198,000 tons to $57 \%$, 659,000 t (Fitzsimmmons, 2000). Considering both the advance of tilapiculture and the rapid

*Author for correspondence 
growth and interest for the fish meat, the demand for the lineages with a satisfactory performance has been increasing, besides the adaptation to the raising environment, thus, attending the perspectives of the markets for the industrialization as well as the sportive fishing.

Studies carried out by Siddiqui and Al-Harbi (1995) comparing different species of tilapia and their respective hybrids during the post-reversion period, as well as evaluating the growth (survival and specific growth), which showed that Nile tilapia (O. niloticus) was the best. Bentensen et al. (1998) observed the growth performance of eight lineages of $O$. niloticus and their hybrids in several raising systems in Asia, with fish species from Africa and noticed that the growth of three African lineages was higher than the Asian ones and that the latter showed a low hybrid vigor.

Several studies have been carried out to evaluate the population genetics, sustentability and evaluation of the strains in order to seek a higher productivity and environmental sustentability. Ramella et al., (2006) observed that the genetic variability of four fish species (Pimelodus maculatus, Prochilodus lineatus, Salminus brasiliensis and Steindachneridion scripta) collected in the upper Uruguay River basin, an analyzed using the RAPD technique, showed high levels of the genetic variability among individuals. Baccarin and Camargo (2005) studied the effect of different feed management on the quality of effluent water generated in Nile tilapia culture ponds, where these authors observed that the effluent water quality decreased in all the treatments.

Dan and Little (2000) supposed differences between the lineages by studying the performance of three lineages of Nile tilapia (Gift, Thai, and Viet) in two types of raising, that is, monosex and mixed cultivation in summer and winter in two breeding systems in the North of Vietnam. From the tilapia fish-larvae species from Nile bred in the winter in both the cultivations mentioned above, the Gift lineage showed a higher final weight when compared with the other two ones. Considering the monosex raising in the three lineages the growth was significantly higher than in the mixed raising $(\mathrm{P}<0.05)$. The growth of the three strains was significantly lower in the incubators than in the tanks.

Wagner (2004), in a study evaluating the productive performance (average daily weight values, apparent feeding conversion, carcass weight and filet weight) of Nile tilapia strains in different breeding phases, compared the intraspecific hybrid (HIB) cross-breeding between the male Chitralada (Thai) and the female Bouaké (Brazilian); the Bouaké internationally known as Nilotica; the Chitralada, the first $\left(\mathrm{CHI}_{1}\right)$ and second $\left(\mathrm{CHI}_{2}\right)$ generations of the Thai strains. The $\mathrm{CHI}_{2}$, the second generation of Chitralada showed the best results.

The aim of this study was to evaluate the zootechnic performance of two strains of Nile tilapia in mixed raising systems.

\section{MATERIAL AND METHODS}

The experiment was carried out at Estação Experimental de Piscicultura of the Universidade Estadual de Maringá, UEM/CODAPAR, located in Floriano, municipal district of Maringá-PR, from November 2003 to August 2004. The experiment was divided in three phases. In Phase I the fish species were allocated in an incubator, and in Phases II and III, these species were transferred to the concrete tanks.

\section{Fish-larvae species Origin}

A total of 3600 Nile tilapia (O. niloticus) was evaluated, 1800 belonging to BOK strain and 1800 to Chitralada strain (CHI). The fish-larvae from the BOK strain was obtained at Estação Experimental de Piscicultura of the Universidade Estadual de Maringá (UEM-CODAPAR) in Floriano municipal district, and the fish-larvae from CHI strain was obtained at Piscicultura Aquabel, located in Rolândia, both of them in Paraná.

\section{Material}

For phases I and II, was used an incubator covered with $50 \%$ wire screens known as screen sombrite. Plastic covering was used on all the sides, in order to protect them from the sudden climatic changes and likely predators. In this shelter, eighteen amianthus cement boxes with a capacity for 5001/water each were used. The water was daily restored at a proportion of $40 \%$. In the third phase, the species were transferred to the concrete tanks with a capacity of 45001, which were covered with a screen in order to avoid the likely predators. 


\section{Diets and Feeding Regimen}

A sort of commercial bran fish-food was used in the Phase I, whereas an extruded fish-food was used in phases II and III, both of them containing $45 \%$ of the crude protein. The feeding was performed four times a day in large quantities, but the wastes were taken out from the tanks through the siphonage to keep the water always clean and, thus, allow an optimum development of the fish species.

\section{Phase I}

In this 88-day phase, 3600 larvae were used, 1800 of them belonging to $\mathrm{CHI}$ strain and 1800 oneweek-old non-sexed BOK larvae strain. The initial average weight and length were $0.7744 \mathrm{~g}$ and $3.48 \mathrm{~cm}$, respectively for the BOK and 1.294 and $4.084 \mathrm{~cm}$ for the CHI. These animals were distributed at random in 18 boxes, nine of them for the BOK strain and nine for the $\mathrm{CHI}$ strain, allocating 200 animals in each. The animals were redistributed when achieved about $9.0 \mathrm{~cm}$ of length and then the phase II was initiated.

\section{Phase II}

Phase II of was carried out in a 22-day-period and the fish species were redistributed once more in the following treatments: T1 (Mixed Bouaké) and T2 (Mixed Chitralada). The initial average weight and length were $4.305 \mathrm{~g}$ and $6.33 \mathrm{~cm}$, respectively for the BOK and $6.520 \mathrm{~g}$ and $7.13 \mathrm{~cm}$ for the CHI. These animals were distributed at random in 18 boxes, nine of them for the BOK strain and nine for the $\mathrm{CHI}$, allocating 40 animals in each.

\section{Phase III}

Phase III was carried out in a 169-day-period and was initiated with fish species with an average weight and length of $8.265 \mathrm{~g}$ and $9.763 \mathrm{~cm}$ for the BOK and $8.661 \mathrm{~g}$ and $11.091 \mathrm{~cm}$ for the CHI. After the incubation, the species were submitted to two treatments with nine repetitions in the concrete tanks with a capacity of $4500 \mathrm{~L}$. Regarding the repetition of each strain, this phase embraced 32 fish species.

\section{Evaluation of the Performance}

In all the phases, the following parameters were evaluated: initial and final weight, gain of weight, initial and final length, gain of length and survival in Phase III in which three biometries were performed. The survival rate in each treatment was calculated based on the difference between the number of species that initiated and ended the phase. The temperature and dissolved oxygen were evaluated daily, and the $\mathrm{pH}$ and the water conductive were monthly observed.

\section{Data Analysis}

The Experimental Outlining was completely used at random, with two treatments and nine repetitions as follows: T1 (male and female Bouaké) and T2 (male and female Chitralada).

The following statistic model was used:

$\mathrm{Y}_{\mathrm{ijk}}=\mu+\mathrm{T}_{\mathrm{i}}\left(\mathrm{S}_{\mathrm{ij}}\right)+\mathrm{e}_{\mathrm{ij}}$

where:

$\mathrm{Y}_{\mathrm{ijk}}$ is the observation of the $\mathrm{i}$ strain in $\mathrm{j}$ repetition of $\mathrm{k}$ sex;

$\mu$ is the general average;

$\mathrm{T}_{\mathrm{i}}$ is the strain effect

$\mathrm{S}_{\mathrm{ij}}$ is the effect between the sexes

eij is the random error associated to each $\mathrm{Y}_{\mathrm{ij}}$ observation

The variance analysis of the performance variables was carried out and the averages compared by using the $\mathrm{F}$ test at $5 \%$ of probability (Banzatto and Kronka, 1995). For the analyses, the Statistic and Genetic Analyses System (SGAS) was used (Euclydes, 1983).

\section{RESULTS AND DISCUSSION}

\section{Physical-chemical Parameters}

The water variables shown in Table 1 have the standard suggested for aquaculture (Boyd, 1990), as well as for the satisfactory development of the specie (Popma and Phelps, 1998), eliminating, thus, their influence regarding the survival of the fish species. 
Table 1 - Average values of both the water temperature and the dissolved oxygen, $\mathrm{pH}$ and conductivity during the experimental phase.

\begin{tabular}{lccc}
\hline Water temperature $\left({ }^{\mathbf{0}} \mathbf{C}\right)$ & $\mathbf{O}_{2} \mathbf{D}(\mathbf{m g} / \mathbf{l})$ & $\mathbf{p H}$ & Conductivity $(\mathbf{m S} / \mathbf{c m})$ \\
\hline $21.25 \pm 3.92$ & $5.35 \pm 1.62$ & $7.92 \pm 0.82$ & $167.94 \pm 18.25$ \\
\hline
\end{tabular}

\section{Performance Parameters \\ Phase I}

The results obtained for the final weight and gain of weight showed that the CHI strain presented the highest values for the final weight and gain of weight. These results were similar to other study carried out during the initial and growing phases with Nile tilapia using $25 \mathrm{CHI}$ and $20 \mathrm{BOK}$ strain. It was observed that the performance was better for the CHI strain, which had a higher gain of weight $(\mathrm{P}<0.05)$ than the BOK strain (Boscolo et al., 2001). The low performance of the BOK probably occurred due to the high consanguinity of this strain, which was introduced in this country for 30 years and originated from an allotment of only 60 individuals (Moreira, 2000). Pullin and Capili (1988) carried out a study in Asia with stocks of tilapia and observed a low productive performance due to the introduction of a small amount of tilapia. The results of the present study were in disagreement with Wagner (2004) who evaluated four strains (intraespecific hybrid, Bouaké, and $1^{\text {st }}$ and $2^{\text {nd }}$ generations of Chitralada) in different breeding phases, regarding the gain of weight. No significant differences was found between the strains when compared with the initial phase. This was probably due to the fact that the species were in the initial phase in which in spite of the significant difference of weight between the treatments, the gain was similar.

In a study comparing the growth of 11 tilapia strains (O. niloticus) and two genetically male lineages (GMT) in the mixed raising, significant differences were also observed regarding the growth between the lineages; both GMT strains presented a higher growth rate in relation to the other ones (Capili et al., 1995).

Table 2 shows the average values of the initial weight (IW) and final weight (FW), gain of weight $(\mathrm{GW})$, and final length (FL) in the Phase I

\section{Phase II}

Table 3 shows the average values of the initial weight (IW), final weight (FW), and final length (FL) of the Phase II. The results showed that there were significant differences between the BOK and CHI strains on weight gain. The CHI lineage showed the higher final weight. The gain of weight of the BOK lineage was better than that of the $\mathrm{CHI}$ strain.

Considering the final length and gain of length, the results were similar. There was no significant differences between both the strains. The results related to the final length were in agreement with those obtained by Romana-Eguia and Eguia (1999), who compared five Asian strains of the red tilapia in the sea environment and concluded that even after 10 weeks, they showed similar lengths. The findings obtained by Tachibana et al., (2004) contradict the results obtained in this study. The authors compared the performance of different strains of tilapia, that is, CESP (C), Pernambuco (P), Thai (T) and Santa Catarina (SC) during the sexual reversion phase and found significant differences $(P<0.05)$ for the final total length, whereas the strains $\mathrm{C}, \mathrm{T}$ and $\mathrm{SC}$ had a higher final length, although PE strain, which presented a lower final length, was similar to SC strain. Jayaprakas et al., (1998) also observed differences among some strains of Nile tilapia; the Chitralada strain showed a faster growth than Bouaké. In this study, the F1 hybrids between both the strain and F2 hybrids (result of the coupling between the F1 individuals) were also evaluated, increasing in average 28 and $37 \%$ more than the pure individuals, respectively. Macaranas et al., (1997) studied tilapias from Israel, Thailand, Mozambique, and red tilapia hybrid. The Thai strain showed a gain of weight significantly higher, reflecting the phenotype/environment relation. 
Table 2 -Average values for Phase I species performance parameters of the different strains of Nile tilapia $(O$. niloticus).

\begin{tabular}{lcccc}
\hline Variable & IW & FW & GW & FL \\
\hline BOK & $0.77 \mathrm{a}$ & $4.30 \mathrm{a}$ & $3.51 \mathrm{a}$ & $6.33 \mathrm{a}$ \\
CHI & $1.29 \mathrm{a}$ & $6.52 \mathrm{~b}$ & $5.25 \mathrm{~b}$ & $7.12 \mathrm{a}$
\end{tabular}

According to Turkey's Test, the averages followed by the same letter in the columns do not differ at a 5\% probability. Caption: Initial Weight (IW), Final Weight (FW), Gain of Weight (GW), Final Length (FL), BOK (Bouaké strain) and CHI (Chitralada strain).

Table 3 - Average values for the species performance parameters in Phase II of different strains of Nile tilapia $(O$. niloticus).

\begin{tabular}{lcccc}
\hline Variable & IW & FW $(\mathbf{g})$ & $\mathbf{G W}$ & FL (cm) \\
\hline BOK & $4.30 \mathrm{a}$ & $8.26 \mathrm{a}$ & $3.96 \mathrm{a}$ & $9.76 \mathrm{a}$ \\
CHI & $6.52 \mathrm{~b}$ & $8.66 \mathrm{~b}$ & $2.10 \mathrm{~b}$ & $11.09 \mathrm{a}$ \\
\hline
\end{tabular}

According to Turkey's Test, the averages followed by the same letter in the columns do not differ at a 5\% probability. Caption: Initial Weight (IW), Final Weight (FW), Gain of Weight (PW), Final Length (FL), BOK (Bouaké strain) and CHI (Chitralada strain).

\section{Phase III}

Tables 4 and 5 (performance between the sexes in the strain) and 6 (performance of the strains between sexes) show the average values of the final weight $(\mathrm{FW})$, gain of weight $(\mathrm{GW})$, final length (FL), gain of length (GL) in Phase III, respectively. After 125 days of raising, there were significant differences for $\mathrm{FW}$ and $\mathrm{GW}$ between the treatments, the moment when the CHI strain showed the best results for both variables in relation to the BOK. These data were in agreement with the studies performed by Romana-Eguia and Eguia (1999) and Wagner (2004), comparing the differences of the productive performance between the tilapia strains. These authors, besides observing such differences, showed the superiority of the Chitralada strain.

After 152 days of raising the FW was different between the lineages, and, the $\mathrm{CHI}$ strain showed the highest value. On the other hand, the GW did not show significant differences. Regarding the FL and GL, there were significant differences between both the lineages, and the CHI strain obtained the best results again. These results disagreed with those obtained by Zanoni et al., (2000) with different lineages of tilapia, during the phase between 30 and $60 \mathrm{~g}$ in average, in which the Chitralada showed a gain of weight higher than the Hybrid and Bouaké strains. After 279 days of raising, the GW and GL were significantly different, an the $\mathrm{CHI}$ obtained a lower value for GW in relation to $\mathrm{BOK}$, which obtained the highest value for the GL in relation to the $\mathrm{CHI}$. Probably, in this last phase the lowest value shown by the $\mathrm{CHI}$ strain regarding the $\mathrm{GW}$, occurred due to the onset of the reproductive process, the moment when the female wastes its energy for the reproduction, what seemed to be an indicative that the $\mathrm{CHI}$ females grew less than the BOK females after the maturity.

Studies carried out by Bromage and Coward (1999) with Tilapia zilli kept with different feeding rates since the post-larvae period until the adult phase observed during a long period of feeding restriction that the tilapia female seemed to sacrifice a gain of weight and body growth in order to maintain the reproductive investment. This implie that if the feeding restriction were used for a long period as a practice to reduce the costs of tilapia maintenance, the reproductive changes related to the body size could occur, not having, thus, any change either of the egg size or the gonadosomatic relation. Balarin and Haller (1982), in studies performed with tilapia females, observed that an inferior growth of up five times concluded that occur, depending on the management adopted.

Considering the final weight, gain of weight and final total length, there were significant differences between the male and female of Bouake strain, the male achieving a higher percentage, that is, 32.83, 57.05 , and $12.38 \%$, respectively for these variables. The same behavior was observed for Chitralada strain, which showed significant differences between the male and female, the male achieving a higher percentage, that is, 78.88, 304.17 , and $19.98 \%$, regarding the same variables. 
Table 4 - Average values for the performance parameters of the fish species in Phase III of different tilapia strains (O. niloticus).

\begin{tabular}{lcccccc}
\hline TRAT & DR & FW $(\mathbf{g})$ & GW $(\mathbf{g})$ & FL $(\mathbf{c m})$ & GL $(\mathbf{c m})$ & S $(\boldsymbol{\%})$ \\
\hline BOK & 125 & $20.26 \mathrm{a}$ & $15.64 \mathrm{a}$ & $12.06 \mathrm{a}$ & $2.30 \mathrm{a}$ & \\
CHI & & $24.81 \mathrm{~b}$ & $21.17 \mathrm{~b}$ & $11.04 \mathrm{a}$ & $-0.04 \mathrm{a}$ & \\
\hline BOK & 152 & $48.77 \mathrm{a}$ & $28.51 \mathrm{a}$ & $12.93 \mathrm{a}$ & $0.86 \mathrm{a}$ & \\
CHI & & $62.89 \mathrm{~b}$ & $38.08 \mathrm{a}$ & $14.45 \mathrm{~b}$ & $3.40 \mathrm{~b}$ & \\
\hline BOK & 279 & $141.02 \mathrm{a}$ & $87.79 \mathrm{a}$ & $18.89 \mathrm{a}$ & $5.43 \mathrm{a}$ & 72.6 \\
CHI & & $134.37 \mathrm{a}$ & $69.33 \mathrm{~b}$ & $18.69 \mathrm{a}$ & $4.08 \mathrm{~b}$ & 73.4 \\
\hline
\end{tabular}

According to Turkey's Test, the averages followed by the same letter in the columns do not differ at a 5\% probability level. Caption: DR (days of raising), Final Weight (FW), Gain of Weight (GW), Final Length (FL), Gain of Length (GL), Survival (S), BOK (Bouaké strain) and CHI (Chitralada strain).

Table 5 - Average values for the performance parameters between the sexes for the tilapia strains $(O$. niloticus $)$ in Phase III.

\begin{tabular}{lccccc} 
Strain & DR & Sex & FW $(\mathbf{g})$ & GW $(\mathbf{g})$ & FTL $(\mathbf{c m})$ \\
\hline BOK & 279 & M & 153.00 & 104.29 & 19.77 \\
& & F & 115.18 & 66.40 & 17.59 \\
\hline CHI & 279 & M & 183.35 & 120.45 & 20.98 \\
& & F & 102.50 & 39.60 & 17.49
\end{tabular}

Caption: DR (days of raising), Final Weight (FW), Gain of Weight (GW), Final Total Length (FTL), BOK (Bouaké strain) and CHI (Chitralada strain).

Table 6 - Average values for the performance parameters of the strains between sexes in tilapia (O. niloticus) in Phase III.

\begin{tabular}{lccccc}
\hline Sex & DR & Strain & FW $(\mathbf{g})$ & GW $(\mathbf{g})$ & TFL $(\mathbf{c m})$ \\
\hline M & 279 & BOK & 153.00 & 104.29 & 19.77 \\
M & & CHI & 183.35 & 120.45 & 20.98 \\
\hline F & 279 & BOK & 115.18 & 66.40 & 17.59 \\
f & & CHI & 102.50 & 39.60 & 17.49
\end{tabular}

Caption: DR (days of raising), Final Weight (FW), Gain of Weight (GW), Final Total Length (FTL), BOK (Bouaké strain) and CHI (Chitralada strain).

Regarding the final weight and final total length, there were significant differences between the males of Chitralada and Bouaké strains, showing that the Chitralada males presented higher values. The female showed significant differences only for the gain of weight, indicating that the Bouake strain female was higher than the Chitralada strain female.

\section{CONCLUSION}

It can be concluded that there was no significative differences between the performances of both strains, and independently of the strains, Bouake or Chitralada, the male performance was always higher than the females.

\section{ACKNOWLEGMENTS}

We thank to CNPq to granting a scholarship and to Estação de Piscicultura Codapar and Aquabel for providing the fish samples for the experiment. 


\section{RESUMO}

O objetivo deste trabalho foi avaliar o desempenho produtivo de duas linhagens de tilápia do Nilo (Oreochromis niloticus) em sistemas de cultivo misto. Foram utilizados 3600 alevinos de tilápia, 1800 da linhagem Bouaké e 1800 da Chitralada. O experimento foi conduzido em três fases, a Fase I realizada em estufa em 18 caixas, nas quais foram testados dois tratamentos (Bouaké e Chitralada) e nove repetições; e a Fase II e III realizadas em 18 tanques de alvenaria, com os mesmos tratamentos. $\mathrm{Na}$ fase I, a linhagem Chitralada apresentou os maiores valores para peso final e ganho em peso. $\mathrm{Na}$ fase II, a Chitralada apresentou o maior valor para peso final em relação à Bouaké, já para o ganho em peso a Bouaké obteve o melhor resultado. Na fase III, a Chitralada apresentou os melhores resultados para peso final (104 dias de cultivo); peso final, comprimento final e ganho em comprimento (152 dias de cultivo) e aos 279 dias de cultivo, o ganho em peso e em comprimento foram maiores para a Bouaké. Estes resultados demonstraram que a linhagem de melhor desempenho foi a Chitralada.

\section{REFERENCES}

Baccarin, A. E.; Camargo, A. F. M. (2005). Characterization and Evaluation of the Impact of Feed Management on the Effluents of Nile Tilapia (Oreochromis niloticus) Culture. Brazilian Archives of Biology and Technology, 48-1, 81-90.

Balarin, J.D.; Haller, R.D. (1982). The intensive culture of tilapia in tanks, raceways and cages. In: Recents Advances in Aquaculture. Mule, J.F. Roberto, R.J. London, p. 265-355.

Banzatto, D.A.; Kronka, S.N. (1995). Experimentação agrícola. $3^{\mathrm{a}}$ ed. Jaboticabal: Funep

Bentsen, H.B. et al. (1998). Genetic improvement of farmed tilapias- growth performance in a complete diallel cross experiment with eight strains of Oreochromis niloticus. Aquaculture, 160, 145-173

Borghetti N.R.B.; Ostrensky A.; BorghettI J.R. (2003). Aqüicultura, uma visão geral sobre a produção de organismos aquáticos no Brasil e no mundo. Curitiba.

Boscolo, W.R.; Hayashi, C.; Soares, C.M. (2001). Desempenho de machos revertidos de tilápias do Nilo (Oreochromis niloticus), linhagens tailandesa e comum, nas fases inicial e de crescimento. Rev. Bras. Zootec., 30, 5, 1391-1396.

Boyd, C. E. (1990). Water Quality in Pounds for Aquaculture. Alabama: Birmingham Publishing Co.
Bromage, N. R.; Coward, K. (1999). Spawning frequency, fecundity, egg size and ovarian histology in groups of Tilapia zilli maintained upon two distinct food ration sizes from first-feeding to sexual maturity. Aquat. Living Resour, 12 ,1, 11-22.

Capili, J.B.; Mair, G.C.; Beardmore, J.A.; Skibinski, D.O .F. (1995). Communal growth comparison of 11 strains of mixed sex tilapia (Oreochromis niloticus L.) and two strains of genetically male tilapia (GMT). 137: 328- 329.

Dan, N.C.; Little, D.C. (2000). The culture performance of monosex and mixed sex new season and overwinted fry in three strains of Nile tilapia Oreochromis niloticus in northen Vietnam. Aquaculture, 184, 221-231.

Euclydes, R.F. (1983). Manual de utilização do programa SAEG (Sistema de Análises Estatística e Genéticas). Viçosa: Universidade Federal de Viçosa Centro de Processamento de dados

FAO 2003, Aquaculture Statistic, 2002. Disponível em: $<\underline{\text { www.fao.org/aquaculture }}>$ Acessado em $10 \mathrm{de}$ outubro de 2006.

Fitzsimmons, K. (2000). Future trends of tilapia aquaculture in the Americas. In: Costa Pierce, B.A.; Rakocy, J.E. (9Ed) Tilapia Aquaculture in the Americas. Baton Rouge, Lousiana: World Aquaculture Society, pp. 252-264.

Jayaprakas, V.; tave, D.; Smitherman, R.O. (1988). Growth of two strains of Oreochromis niloticus and their F1, F2 and backcross hybrids. In: PULLIN, R. S. V.; Bhukaswan, T.; Tonguthayi, K.; Maclean, J.L. (Ed.) The Second International Symposium on Tilapia in Aquaculture. Manilla, Philippines: ICLARM, 197-201. (ICLARM Conference Proceedings, $\mathrm{n}^{\circ} 15$, pp. 197-201.

Macaranas, J.M.; Mather, P.B.; Lal, S.N.; Vereivalu, T.; Lagibalavu, M.; Capra, M.F. (1997). Genotype and environment: A comparative evaluation of four tilapia stocks in Fiji, Aquaculture, Amsterdam, 150, 11-24

Moreira, H.L.M.; Dellagostin, O.A.; Erdtmann, B. et al. (2000). Levels of inbreeding and relatedness in breeder stocks of Nile tilápia (Oreochromis niloticus) detected by microsatellite analysis. In: Tilapia aquaculture in the 21 century, 1, 2000, Rio de Janeiro. Proceedings $\mathrm{n}^{\circ} 22$. Rio de Janeiro., 59-76, 1.

Popma, T. J.; Phelps, R. P. (1998). Status report to commercial tilápia producers on monosex fingerling productions techniques. In: Aquaculture Brasil, 10., Recife. Anais... Recife: ABRAq, pp. 127-145.

Pullin, R.S.V.; Capili, J.B. (1988). Genetic Improvement of tilapias: problems and prospects. In: PULLIN, R.S.V.; BHUKASWAN, T., TONGUTHAI, K., MACLEAN, J.L. (Eds.). The second International Symposium on Tilapia in Fisheries, Bangkok, Thailand and International Center for Living Resources Management. Philippines, pp. 259-265. 
Ramella M.S.; Kroth, M.A.; Meurer, S.; Nuñer, A.P.O.; Filho, E.Z.; Arisi, A.C.M. (2006). Genetic Variability in Four Fish Species (Pimelodus maculatus, Prochilodus lineatus, Salminus brasiliensis and Steindachneridion scripta) from Uruguay River Basin. Brazilian Archives of Biology and Technology. 49-4, 589-598.

Romana-Eguia, M.R.R.; Eguia, R.V. (1999). Growth of five Asian red tilápia strains in saline environments. Aquaculture, 173, 161-170.

Siddiqui, A.Q.; Al-Harbi, A.H. (1995). Evaluation of three species of tilapia, red tilapia and a hybrid tilapia as culture species in Saudi Arabia. Aquaculture, 138, 145-157.

Tachibana, L.; Castagnolli, N.; Pezzato, L.E.; Barros, M.M.; Valle, J.B.; Siqueira, M.R. (2004). Desempenho de diferentes linhagens de tilápia do Nilo (Oreochromis niloticus) na fase de reversão sexual. Acta Scientiarum, 26, 3, 305-311.

Wagner, P.M.; Ribeiro R.P.; Moreira H.L.M.; Vargas L.; Povh J.A. (2004). Avaliação de linhagens de tilápia do Nilo (Oreochromis niloticus) em diferentes fases de criação. Acta Scientiarum, 26, 2, 187-196.

Zanoni, M. A.; Filho, M.C.; Leonhardt, J.H. (2000). Performance de crescimento de diferentes linhagens de tilápia-do-Nilo, Oreochromis niloticus (Linnaeus, 1758), em gaiolas. Acta Scientiarum, 22 (3), 683-687. 